\title{
REREONGAN SERUMPI FOR RURAL DEVELOPMENT IN SITU UDIK VILLAGE BOGOR WEST JAVA
}

\author{
Endin Mujahidin $^{a)}$, Bahagia $^{\left.a^{*}\right)}$, Rimun Wibowo ${ }^{b)}$, Fachruddin Majeri Mangunjaya $^{c}$ ) \\ a) Universitas Ibn Khaldun, Bogor, Indonesia \\ ${ }^{b)}$ STIMMA IMMI, Jakarta., Indonesia \\ ${ }^{c)}$ Graduate School, Universitas Nasional, Jakarta, Indonesia \\ ${ }^{*}$ Corresponding Author: bahagiagia59@yahoo.co.id
}

Article history: received 23 August 2020; revised 27 August 2020; accepted 30 August 2020

\begin{abstract}
The objective of this research to investigate about rareongan sarumpi for rural development in Situ Udik Village Bogor West Java. The research method used qualitative approach. The data are gathred through in-depth interviews, observation, and documentation. The selection of sample as informant exert purposive sampling technique. The result is the leader of village exert non hierarchy and range between society and chief of village. The impact is leader and society are mutual support. The other is community development in Situ Udik village use bottom-up action like rereongan serumpi for society. The resources come from society and give back again result to society. The other is rereongan serumpi conserve gotong royong as cultural. The implementation of rereongan serumpi utilize mutual cooperation (gotong royong). People applicate togetherness, willing to help another people as well as conserve charity for assisting people. Lastly, rereongan serumpi is related to social capital. Individual and other person in inside group have strong social binding as well as society build social connection outside of local people..
\end{abstract}

Keywords: Rereongan serumpi; Gotong Royong (mutual cooperation); social capital; rural

\section{INTRODUCTION}

Rural development confront to numerous hurdle including poverty community in village. The number of poverty in village is about 17893,73 citizenship or around $14,09 \%$. Meanwhile the number of destitution in city is around 10619,87 inhabitant or $8,22 \%$ from total of population in Indonesia [1]. One indication of poverty society in village inhabitate unlivable house. It conect to incapability of people for building house because economic factor. While house is fundamental necessities of person. House must be provided like food need without livevable house, person can be categorized as impoverished. In order to flourish rural area must be included creativy of society. One indicator is the role and style of leader in rural area. As leader of village can drive the resources in rural area, village can attaint goal without poverty. Rural development must be involved local people who is perpretator in button up level.

Activity for rural development will not unsucessfully without supporting from society. Village also can react goal when social capital in community of people have embeded as soul. Social capital refers to the characteristics of a group or community enabling the fulfillment of a collective aspiration (Jovita [2]). Social capitall include bonding social capital describes relationships established between individuals who are very similar in terms of origin, culture and religion and bridging social capital, which characterises those relations which exist among individuals who are culturally more different, produces an unequivocally positive long-term return (Östh [3]). Furthermore, rural development must be include society as capital. People in rural area rely on another people to fulfill their need. The impact is among them must severe solideraty especially inside of the communit.

It must be strenghtened by another resources like conection of inside community. The linkage between outside and inside of society can enchan development in village. The another pivotal for build society in village is cultural namely Gotong Royong. It refer to people work together for public objective without obtaining money as reward but the person who have inclueded must contribute to another people who need a help. Rosyani [4] remark that gotong royong is social capital. Participaction of people in rural is pivotal role to reach goal of development (Sembel [5]). One action of participation is gotong royong (Mutual cooperation). Gotong royong is related to participation all of member people in rural are for development as well as gotong royong have solidarity value. Therefore solidarity principle is severe imperative for development for Indonesia citizenship (Yani [6]).

Gotong royong have been implied in numerous activity such helping people who experience eco-catasthrope and agriculture (Pasya [7]). In gotong royong, there is concern value among of people to tie person for togetherness action and restrict individul freedom (Endro [8]). However, gotong royong create social cohesion and applicate numerous of activity like harmony cummonity. The objective is to build solidity among of member (Wardiat [9]). In numerous costumary community like kampung Naga, they implement mutual working in some activity like agriculture especially in harvesting periode, inventing and improving of community house as well as ceremony party community (Rolitia [10]). 
Gotong Royong also applicate to green movement such as people planting trees (greening area) in village, garbage manajement and deposite of water as well as releasing urban agriculture such as vertical, sky, and flying garden. This research will search about rereongan serumpi for development of rural area in Situ Udik village, Cibungbulang Regency West Java. There area some investigating including the role and style of leader in village for flourish rural area. The another is to obtain data related to cultural like Gotong royong value in rereongan serumpi as action program which come from leader of village for society as button of movement instead of top down mechanism. Lasty to find social value of rereongan serumpi.

\section{RESEARCH METHODS}

Research that has been conducted in the case of The research about Rareongan Sarumpi for Rural Development in Situ Udik Village Bogor West Java. The method use is qualitative with indept-interview. Qualitative method is used to understand people's beliefs, experiences, attitudes, behavior, and interactions (Pathak [11]). This means that qualitative researchers study things in their natural settings, attempting to make sense or interpret, phenomena in terms of the meanings people bring to them (Aspers [12]). In order to select respondents use Purposive Sampling technicue. There are two people are utilized as sample including leader of Situ Udik namely sir Enduh Nuhudawi. He is selected as sample due to he have created rereongan serumpi as action for rural development.

The another key person is Desta. He is key person for young generation of Situ Udik Village. Data are collected including bottom-up developmen base on society because people through chief of village have creativity to initiate Rereongan serumpi as action. The another data will be gatherd is style of leader in rural area for flourish of rural area. It continue to investigate social and gotong royong as cultural value in Rereongan serumpi. Data will be supported by another sources including journal and books which are directly conected with research goal. It was followed by observation.

Observer takes notes on everything or certain predetermined parts of what is happening around them, for example focusing on physician-patient interactions or communication between different professional groups (Busetto [13]). Observation can collect data regarded with real fact of rarengon serumpi in rural area [14]. All data are probed meticulously by triangulation data for getting valid data. The combination of sources namely triangulation data can assert valid data. In this research mixing data from observation sources, In-depth interviews, and documentation can produce trusted data.

\section{RESULTS AND DISCUSSION}

Rural area still face to some obstacle including people in village still live in poverty rate and have hardship situation for fulfiling fundamental necessities. It can compounded by people dwell in unproper house for continuing life. Action to combat this issues have been released for last decade. However, in rural area person still experience this problem. The principle to develop rural area can be reacted as person as actor and utilize human and local resources. The problem is rural people is created become slugish person like they receive money case for helping without implementing their heavy endeavour.

On the other hand, this action is look like the best way to assist the person. If it continue, it can create person who lose their creativity because they can receive money without working. It can be peril person character because they will wait for helping instead of producing action for aiding their self. It can better as people in rural area give capital for creating creativity work. In long future, they have benefit form their endevour and reduce depending on helping from country. In Situ Udik village, the action for rural development come from leader of rural area namely Rereongan serumpi.

The activity is severe simple because in the field, the officer which is appointed by chief of village about 2-3 person each day will visit the people house for asking money around RP. 100 rupiah/person/each day. The number of population of Situ Udik Village is about 14000 citizenship. Each month, the amount of money that can be collected about RP. 40.000.000. The money which is gathered will distribute to person who need it most namely who they house can be categorized as unproper living. Rereongan serumpi is not goverment action but come directly from Bottom-Up level or from grass root. The leader of Situ Udik village have created it when he convince as chief in village.

It indicate that leader have imperative role to flourish rural development. When leader have motivation to react rural area free from poverty, chairman must have extraordinary action or ideas like in Situ Udik create Rereongan serumpi. Leader have to understand comprehensively about societies issues and what the people need most. Leader like chief of Situ Udik village applicate humble and simple to person. Even leader behave like society. Leader like a service person to people, leader hate to use his room for receiving guest both outside of community and inside.

Enduh as a leader convey that the person will be awkward if he stay at room when his society visit his to his office. Even uniform must be changed like cloth of the people in grass root level because it can build positive image from society. It indicate that no significantly hierarchy among leader and society. As consequence as society will not be clumsy consult their problem. Finally, sir Enduh determine to sit in waiting room to service the person instead of bringing them at room. He also think that leadership include position is mandatory. The style like this can close society to leader. The impact is society can build conection and communication to leader for what they problem must be completed together.

Local residents stated that they pay more attention and cooperation to their leader when the leader is always communicating and working with them (Rami [15]). Beside 
that effective leadership which is the ability to build good relations with stakeholders (inhabitants, entrepreneurs, nongovernmental organisations, etc.) and the use of social potential, is considered to be an essential factor that affects the functioning of local communities and their success (Springer [16]). Interaction between leader and community can enchan sustainability (Hermawati [17]).

Leader must be catalysts, leaders should double their efforts and works to encourage people to work together to develop their communities. The another advantage of rereongan serumpi is action to empower society come from their creativity to aid they issues as well as giving solution for the problem instead of action come from goverment. The leader of village have created Rereongan serumpi for assisting society for reacting prosperity. The resources like finance capital come from societies rather than from factory, expert and goverment, the community will preserve it because they think that it is their own as well as human resources.

Even they will continue it for forthcoming. People will pursue it because they strunggle for it. Local people and local of economic finance as sources for assisting them. The impact is society can scale up the capacity of people to optimalize in usage of local resources. Community capacity refers to the ability of residents to organize and mobilize their assets and resources to achieve development objectives that they consider important (Markey [18]). Goverment directly have been enchanced by Rereongan serumpi because there is integration between goverment action and societies approach. The action also can reduce the rate of independence rural and goverment center.

Bottom-up approach where all stakeholders have equal opportunities to participate in policy formulation and implementation (EL-Asmar [19]). Conversely, Sylva [20] reveals that top-down approaches continue to be the preferred development models of government and donor organization. Roitman [21] remark that community participation seems to be limited to the initial stages of the programme and later the decision-making processes are carried out within the elite group of the community or at the national government level. In Situ Udik village whole people have involved to assist another person typically for ditributing funding for rehabilitation of house which is owned by poverty person.

Despite the people who involve don't gain economic merits (Effendi [22]). Society in village have invented their house but house require to rehabilitate due to unlivable house for them. A bottom-up approach was more amenable in facilitating community participation and in engaging with the poor settlements (Annamalai [23]). Isidiho \& Sabran [24] said that button up can encourage local community and local players to express their views in defining the development course for their area in line with their own views, expectations, plans and their sociocultural life style. The another merits is funding which is collected will be controled by many person because all person in village contribute to aid another person. The impact is action for house improving will be supervised by public people in rural area rather than village officer. Village officer must held mandatory and assert to contributor that financial capital must be allocated to vulnerable person. As result as officer of village will not dare to smugle funding because there is public watching for it.

Bottom-up approach like Rereongan serumpi have strong role to combat poverty rate in rural area because people who have strict restriction for building proper house for living. The major purpose of funding from Rereongan serumpi is distributed funding to people who need to build house. One is the bottom-up approach where individuals and groups of villagers work innovatively in developing new building construction opportunities, prompted by contemporary and indigenous design and construction method (Gao [25]). Funding which have been gathered from each people will be implied to rehabilitation typically unproper house for society or improve slight demaged.

The small demaged house will be allevieted directly without distributing funding directly to person who own of the house. Leader of village delegate worker who responsible to improve house as well as purchase material which is utilized for improving house. Rereongan serumpi involve improving activity of house because house is fundamental necessities of society. House is place for rest and sleep. House also as symbol of economic of people, when someone can build luxury house, meaning that person can categorized as hight class person. Poverty level and house is extreamly conected and people still in vulnerable situation when person can't build proper house.

Person can't build house because there is conection between vulnerable condition and the quality of house. The impact is person require to gain assistance both material and funding for building of house. It leads to person can't releases to buil proper house because it is hardship for midle class person up to button level of society. Event it just beauty dream for poverty people to own proper house (Hikmawati [26]). Destitution results to person can't fulfill basic need, health, clean water, sanitation as well as person is restricted to own livable house. The impact is to rise slum area (Andriana [27]). Furthermore, rereongan serumpi conserve social capital among member of people and officer in village.

When society convince to officer for using funding which have been gathered, meaning that people in Situ Udik have trusted fully to officer that funding will be given to people who need improve their house become prover house. When trusting as become behavior, it leads to abolish negetive image about village officer. Hight trusting can measured when people don't demand about the treaty paperly but society render finance resources to village officer. As result as trust can boost public involvement (Riniati [28]). The another value of Rereongan serumpi is tradition and cultural. Mutual work or mutual cooperation is social and cultural capital for build of rural area.

If tradition and cultural vanish from rural, society will be unlikely for developing. Cultural have strong linkage to Rarengongan serumpi because gotong royong is rarengongan serumpi. While gotong royong (Mutual working) is related 
to cultural and social value. Gotong Royong can be created because there is helping from other person for private and collective objection (Taslin [29]). Member of society in Situ Udik have strong sense that they must aid the another person socially and culturally. There is hope when assist other person like thinking that it produce advantage another time. People who behave it will gain benefit. Gotong Royong (mutual cooperation) value in rereongan serumpi where all the society willing to distribute their wealthy to another person for aiding person.

There is collective action around them when conduct this action. Togetherness is related to collective cooperation. Solidarity can decline burden, It assertain the more stronger social capital the more resilience and the more strunggle as well as improve life quality of people (Solikatun [30]). Application the program will not released when whole member don't encourage it. In this case, people work together among village clerk who gather money from society and all member people in village underpin action of village officer. Immediately, cultural like gotong royong can be protected in rural area. While protecting gotong royong can boost development in village.

Conversely, rural area will fail to developt as gotong royong vanish from people. Even all the people comprehend that another people must be assisted by other person. It unable to act when they don't have strict social binding among people in rural area. The people think that another person are theit brother, the impact is neighbour is their brother. Brother principle in village witout look wheater they brother biologically. It become strong glue for the community. There is heavy internal relation inside the community (social binding). There are tree part of social capita; encompases bonding social, bridging and social lingking capital (Abdullah [31]).

Bonding capital have imperative role to encourage people in participating of empowerment program (Riniati [32]). Bonding social capital is glue inward looking dan bridging social capital is network outside of community (outward looking) (La Ola [33]). People in Situ Udik have social glue as bonding social capital through Rereongan serumpi because person with another person fight to refine other person life. The impact is people who initially dwell in uninhabitable house can settled in livable house. In Rereongan serumpi, when person tend to distribute money without eager to gain merits back to perpretor, it indicate person have hight charity to person.

There is principle that if we assist other person, it similiar to help yourself (Bagas [34]). While people who willingly to distribute money to person can be categorized as the best person because they just give finance but the status is not lended. However, people in Situ Udik especially village office continue to preserve networking outside of community like center of goverment. It can be supported Rereongan serumpi as creativity of society with action from goverment to rehabilite of house as well as another development purpose. The spirit development between power and energy come from goverment and society can be solution comprehensively to reduce poverty in rural area.
Conversely, as society doesn't underpine goverment action, development can't react goal of development. Lastly, people in rural area who they include in Rereongan serumpi have been implemented religion teaching. The same religion can boost social binding. People beleive that when they give 100 rupiah for person, they will gain reward from goodness. Person convince that it create person wealthy if they expend their subsistence to help another person. There are prosperity that people convince including fortune from goodness and from their action. Logically, it difficulties to perceive but it is fundamental principle in Situ Udik village.

\section{CONCLUSION}

There are numerous aspects of this research can be determined including Rereongan serumpi is action for rural development which is created by society in village typically leader of village. Development of rural area can sucesfully when action not juts come from center of goverment but it must be created by society. The mechanisme of development can be categorized as bottom-up development. The another is leadership style of leader in village applicate non hirarchy. The impact is society and leader of rural area are severe closed. It leads to build better relation between society and leader of village. The another is rereongan serumpi is action which conserve gotong royong (mutual cooperation) as well as tradition or cultural. People in village must implement mutual helping among of them.

\section{REFERENCES}

[1] BPS.2016. Statistik Indonesia. Jakarta: Badan Pusat Statistik.

[2] Jovita, H.D., H. Nashir, D. Mutiarin, Y. Moner \& A. Nurmandi (2019): Social capital and disasters: How does social capital shape post-disaster conditions in the Philippines?, Journal of Human Behavior in the Social Environment. Jurnal Analisa Sosiologi 7(2): 262-273.

[3] Östh, O.J., M. Dolciotti, A. Reggiani \& P. Nijkamp. 2018. Social Capital, Resilience and Accessibility in Urban Systems: a Study on Sweden. Netw Spat Econ 18:313-336.

[4] Rosyani., F. Muchlis, D. Napitupulu \& H. Faus. (2019). Gotong royong (cooperation) transformation of rural communities in Jambi Province Indonesia. Jurnal Perspektif Pembiayaan dan Pembangunan Daerah 7 (1):103-110.

[5] Sembel, T., R. Gosal, S. Pangemanan. 2017. Partisipasi masyarakat dalam pembangunan desa (studi di desa Sinsingon Barat Kecamatan Passi Timur Kab Upaten Bolaang Mongondow. Jurnal Excecutive 1 (1):1-11.

[6] Yani, T.A. 2017. Pembangunan gampong dengan semangat gotong royong melalui musyawarah dan 
keterbukaan di kabupaten Aceh Barat. Journal Public Policy 3 (2):150-159.

[7] Pasya, G.K. 2011. Gotong Royong Dalam Kehidupan Masyarakat. Sosietas: Jurnal Pendidikan Sosiologi 1 (1):1-12.

[8] Endro Gunardi. 2016. Tinjauan Filosofis Praktik Gotong Royong. RESPONS 21 (01):89 - 112.

[9] Wardiat, D. 2016. Dinamika Nilai Gotong Royong Dalam Pranata Sosial Masyarakat Nelayan: Studi Kasus Masyarakat Bulutui Dan Pulau Nain, Sulawesi Utara. Jurnal Masyarakat \& Budaya 18 (1):133-146.

[10] Rolitia, M., Y. Achdiani \& W. Eridiana. 2016. Nilai Gotong Royong Untuk Memperkuat Solidaritas Dalam Kehidupan Masyarakat Kampung Naga 6 (1):1-17.

[11] Pathak, V., B. Jena, S. Kalra. 2013. Qualitative research. Perspect clin res 4(3):192.

[12] Aspers, P. \& Corte, U. (2019). What is qualitative in qualitative research. Qualitative Sociology, 42, 139- 160.

[13] Busetto, L., W. Wolfgang \& C. Gumbinger. 2020. How to use and assess qualitative research methods. Neurological Research and Practice 2 (14):1-10.

[14] Busetto, L., Wick, W. \& Gumbinger, C. How to use and assess qualitative research methods. Neurological Research and practice. 2 (14):1-10.

[15] Rami, A.A.M.D., R. Abdullah \& M.H.A. Simin. 2017. Influence of leadership in rural community development in the state of terengganu, malaysia. Asian Journal For Poverty Studies 3(1): 47 - 52.

[16] Springer, A., K. Walkowiak \& A. Bernaciak. 2020. Leadership Styles of Rural Leaders in the Context of Sustainable Development Requirements: A Case Study of Commune Mayors in the Greater Poland Province, Poland. Sustainability 12 (2676):1-15.

[17] Hermawati, W. 2019. Local Leadership and Microhydro Project Sustainability in Rural Indonesia. Indian Journal of Public Administration 65 (3) 687701.

[18] Markey, Sean, Greg Halseth, and Don Manson. 2012. Investing in Place: Economic Renewal in Northern British Columbia. Vancouver, British Columbia: UBC Press.

[19] EL-Asmar, J.P., Ebohon, J.and Taki, A.H. (2012) Bottom-up approach to sustainable urban development in Lebanon: The case of Zouk Mosbeh. Journal of Sustainable Cities and Society 2 (1): 37-4.

[20] Sylva, S.D. 2017. Taking Back Control: Issues and Benefits of Bottom-up Redevelopment. Procedia Engineering 212: 348-355.

[21] Roitman S. (2016). Top-Down and Bottom-Up Strategies for Housing and Poverty Alleviation in Indonesia: The PNPM Programme in Yogyakarta. In: Attia S., Shabka S., Shafik Z., Ibrahim A. (eds) Dynamics and Resilience of Informal Areas. Springer Cham:187-210.
[22] Effendi, T.N. 2013. Budaya Gotong-Royong Masyarakat dalam Perubahan Sosial Saat Ini. Jurnal Pemikiran Sosiologi 2 (1):1-18.

[23] Annamalai, T.R., G. Devkar, A. Mahalingam, S. Benjamin, S.C. Rajan, A. Deep. (2016) What is the evidence on top-down and bottom-up approaches in improving access to water, sanitation and electricity services in low-income or informal settlements? London: EPPI-Centre, Social Science Research Unit, UCL Institute of Education, University College London.

[24] Isidiho, A.O., \& M.S.B. Sabran. (2016) Evaluating the Top-Bottom and Bottom-Up Community Development Approaches: Mixed Method Approach as Alternative for Rural Un-Educated Communities in Developing Countries. Mediterranean Journal of Social Sciences 7 (4):266-273.

[25] Yun Gao. 2016. Top-down and bottom-up processes for rural development and the role of architects in Yunnan, China. Buildings 6 (47):1-21.

[26] Hikmawati, E., \& T. Gutomo. 2015. Bedah Rumah sebagai Bentuk Pengentasan Kemiskinan House Rehabilitation as Poverty Elimination Form. Jurnal PKS 15 (2): 131-144.

[27] Andriana,L., \&Manaf.A. 2017. Relevansi Aspek Kemiskinan dan Fisik Lingkungan Kumuh Pada Penentuan LokasiPenerimaProgram KOTAKU (Studi Kasus: Kecamatan Pamekasan Kabupaten Pamekasan). Jurnal Pengembangan Kota. Vol 5 (2): 131-139.

[28] Riniati, R. (2017). Analisis Bridging, Linking dan Bonding Social Capital pada Pemberdayaan Ekonomi Masyarakat Berbasis Teknologi Informasi dan Komunikasi (TIK) (Studi Kasus di Desa Kertosari, Kec. Pasrujambe, Kab. Lumajang, Jawa Timur). Jurnal Ekuilibrium 1 (2): 28-35

[29] Taslin \& Yusuf. 2017. Nilai-nilai gotong royong dalam pembangunan desa pada masyarakat Siompu (Studi di Desa Karae Kecamatan Siompu Kabupaten Buton Selatan). SELAMI IPS 46 (2):152-163.

[30] Solikatun, Nuning Juniarsih. 2018. Modal sosial sebagai srategi bertahan hidup masyarakat Desa Maria, Kecamatan Wawo, Kabupaten Bima, Provinsi Nusa Tenggarabarat. Jurnal Analisa Sosiologi Oktober, 7(2): 262-273

[31] Abdullah, S. (2013). Potensi dan kekuatan modal sosial dalam suatu komunitas. Socious: Jurnal Sosiologi 12 (1):15-21.

[33] La Ola, T., N.I Wianti, M. Tadjuddah. 2020. Bridging dan bonding social capital: analisis relasi sosial masyarakat pulau-pulau kecil di Taman Nasional Wakatobi. Sodality: Jurnal Sosiologi Pedesaan 08 (01): 30-46.

[32] Riniati., A.Suman, K, Ashar, A. Manzilati. 2017. The role of social capital on information and communication technology based empowerment (Case Study in Kertosari Village, Pasrujambe District, 
Lumajang Regency). International Journal of Social and Local Economic Governance 3 (2): 69-73.

[34] Bagas \& M. Radjab. 2019. Tergerusnya Gotong Royong di Desa Tadang Palie Kecamatan Ulaweng Kabupaten Bone. Hasanuddin Journal of Sociology 1 (2):116-126. 